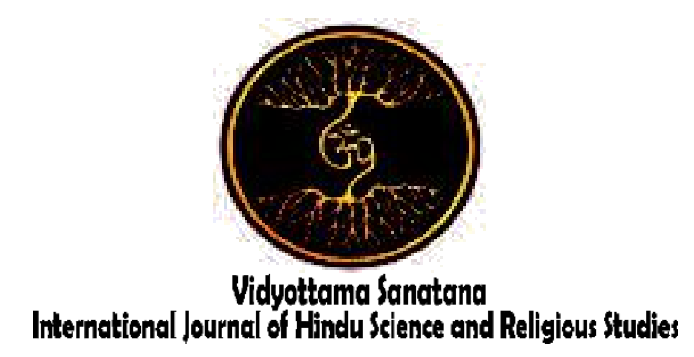

Vol. 4 No. 1 May 2020

\title{
HINDUS LEADERSHIP TEACHING IN GEGURITAN NITI RAJA SASANA
}

\author{
By: \\ Putu Sanjaya $^{1}$, I Nyoman Suarka ${ }^{2}$, Ni Made Indiani ${ }^{3}$ \\ ${ }^{1}$ STAH Negeri Mpu Kuturan Singaraja \\ ${ }^{2}$ Universitas Udayana \\ ${ }^{3}$ Universitas Hindu Indonesia \\ E-mail : ${ }^{1}$ putusanjaya947@gmail.com, ${ }^{2}$ nyoman_suarka@unud.ac.id, \\ 3indianimade@gmail.com
}

\begin{tabular}{|l|l|l}
\hline Received: December 16, 2019 & Accepted: May 12, 2020 & Published: May 30, 2020
\end{tabular}

\begin{abstract}
The teachings of Hindu leadership in the Geguritan niti raja sasana, related to how the obligation as a leader needs to be applied in leading a kingdom, state or institution in order to create peace and prosperity for the people they lead, As a research method, qualitative research views an object or reality not partially or broken down into several variables. Qualitative research sees the object as something dynamic, the result of thought construction and interpretation of the observed phenomena, as well as holistic, because every aspect of the object has a unity that cannot be separated. initiates the teachings in Geguritan Niti Raja Sasana namely Dwidasa Pratingkahing Prabhu which constitutes 12 (twelve) compulsory behaviors carried out by a king (leader), subsequently successive teachings from Geguritan Niti Raja Sasana namely Catur Pariksa, Sad Dasa Brata which are sixteen self-attitudes that must be carried out by a leader. Tri Tataning Kamantrian concerns on the wealth of a king (leader) is to have a wise mantri (minister), Tri Suragapan is a teaching that gives instructions to a king (leader) not to do three prohibited things, Tri Ulahing Budhi related to the attitude of the leader on a noble basis good budhi, and regarding the duty of a king or leader contained in the teachings of Rukma Bhisama. Asta Brata is a symbol of the nature that must be owned by a king (leader) or head of the state. Catur Sopeksa is a teaching of the leader's behavior procedures. Catur Pariksa Nagara Krama, consists of the leader's vigilance attitude, and a leader who is able to control his five senses is not excessive in fulfilling the wishes set forth in the Panca Raksa.
\end{abstract}

Keywords: Geguritan, Niti Raja Sasana, Leader, Hindu 


\section{INTRODUCTION}

A society or country will be easily regulated when its members are aware of their rights and obligations. The effort of each citizen to increase their prosperity including their family and environment will affect the prosperity of the country. The state leaders and their family must be a role model for their citizens. The personal and family life of the leader must be approved and set as an example for the life of the citizens and their family (Pasek et al, 1982: 5). Hindus literatures that contain the teachings of dharma provides guidance to the people' to reach the perfection for their life in the nation. Pasek et al (1982: 2) explain that life's guidelines are contained in various holy books along with their literature. As a small example, in Hinduism there are guidelines for people who have the opportunity to lead the country. In Hinduism there is also guidance for the people or citizens who aim to form an obedient participant or citizen. While the guidelines for those who have the honor to lead the country aim to form good state leadership and form a strong and clean state apparatus. Thus an assumption can be taken that Hinduism can be a source of inspiration in shaping and stabilizing a view of the life of the nation and country where Hinduism is embraced. In other words, Hinduism contains crystals of religious life values. These value crystals can be used as sources that have the function to integrate society into the state administratif

Hinduism has a lot of literatures that can be used as a guide, related to the guidance of life in direct contact with leaders and leadership. One of the literatures which contains the teachings of leadership is Geguritan Niti Raja Sasana. Geguritan Niti Raja Sasana is one of many geguritans in Bali. Geguritan Niti Raja Sasana contains leadership teachings that are very useful for fostering human behavior, especially for a leader who has an obligation to carry out the task in increasing his people' welfare. The teachings that contains in the Geguritan Niti Raja Sasana, especially the teachings on Hindu leadership are very important as guidelines for behavior, especially in today's various forms of leader actions that reflect the existence of moral degradation in the community. Geguritan Niti Raja Sasana is a literary work that can be a source of guidance on the teachings of Hindu leadership both individual and social, especially in terms of leadership. There are various leadership teachings contained in Geguritan Niti Raja Sasana. As well as, the advice presented in Geguritan Niti Raja Sasana can also be used as a guidance, sepat siku-siku (guidance), or a reflection of life.

\section{METHOD}

Qualitative research sees the object as something dynamic, the result of thought construction and interpretation of the observed phenomena, as well as holistic, because every aspect of the object has a unity that cannot be separated. Reality in qualitative research is not only what is seen or observed, but goes beyond what appears. Reality is the construction or interpretation of an understanding of all data that appears in the field. The location of the determination of this research is in the Regency of Buleleng with the capital Singaraja chosen as the location of this study because Singaraja is a city that has long been rated as a city of education. This of course can be as a carrying capacity in exploring potential things that can be used as material or educational material. Related to literary works, literary activist activities in Buleleng Regency can be said to be alive. This is proven by the existence of magagitaan programs in several public and private radio stations in Singaraja, and the data collected or collected in this study are qualitative data, which are data in the form of words, sentences, descriptions, and also verbal explanations. Qualitative data in the form of writing that the author obtained from the text Geguritan Niti Raja Sasana as the main data, which is supported by data that the author obtained through other texts and also from interviews with informants. The data obtained in this study are primary data that is obtained directly in research by researchers, as well as secondary data in the form of data based on 
existing sources, with observation techniques, interviews, and documentation the authors use to collect data related to teaching implementation problems the leadership found in Geguritan Niti Raja Sasana in Buleleng Regency.

\section{RESULT AND DISCUSSION}

Geguritan Niti Raja Sasana contains the teachings of Hindu leadership. The teachings of leadership in Geguritan Niti Raja Sasana are as follows:

\section{Dwidasa Pratingkahing Prabhu}

The teaching of Dwidasa Pratingkahing Prabhu that contains in Geguritan Niti Raja Sasana is 12 (twelve) behaviors that must be carried out by a king (leader). As contained in the quote Geguritan Niti Raja Sasana Pupuh Smarandhana I verses 6-10 one of them are as follows:

Mungguh ring ulahē sami, nē mangkin sikisikiang, cacakan ring kapisane, asih ring warga daridra, kaping kalih punika, asih ring wong kawelas hyun, ping tiga sih ring pandita.

Translation:

Containing in all the behaviors, it is mentioned one by one, the first part, loving the poor citizens, the second, loving people who has love in his mind, the third, loves or respects the Pandita.

Based on the quote of Geguritan Niti Raja Sasana above can be described 12 teachings as follows:

\section{Asih ring warga Farida}

Asih ring warga daridra means to love or feel sorry for people who are miserable, poor, or afflicted by unfortunate conditions. A leader should have concern and empathy for people who have bad luck as well as people who are afflicted by misery, being in poverty, and misfortune. Without empathy, humans will be selfish, live solitary, intolerant, maybe even cruel. Empathy is related to many things, such as thoughts, beliefs, and desires of a person related to his feelings, someone who empathizes will be able to know the mind and consciousness of the soul or mood of others.
The attitude of love or compassion for people who are miserable, poor, or afflicted by unfortunate needs to be shown as a dimension of human feelings.

\section{Asih ring wong kawelas hyun}

Asih ring wong kawelas hyun means loving those who are full of compassion. Love is experienced by every human being, because love is a part of human life. Hinduism teaches its people to always support and love one another

\section{Sih ring pandita,}

Sih ring pandita means loving or respecting the pandita (priest). Understanding pandita according to Ngurah.dkk (1999: 161) is a priest who is classified as dwijati.

\section{Bhakti ring widdhi}

Bhakti ring widdhi means worshiping God. Sanjaya (2016: 1) explains that Hinduism is a religion that has the goal of realizing jagadhita, namely a life that is safe, peaceful, and prosperous. Worship to Hyang Widhi and all his Prabhawa is a must.

\section{Tan lupa puja mantra}

Tan lupa puja mantra means not forgetting to worship. Worship to God can be done by chanting holy mantras, which are termed chanting.

\section{Pratingkahe nggae patut}

A leader must always behave properly. A good relationship starts with good behavior from each individual. Everyone certainly wants good treatment from others, it will be realized if he is able to show good behavior towards others. In simple way, good relationships or interactions are manifested by the good behavior displayed by everyone.

\section{Manglehin wadwa bala}

A leader must know which subordinates have dedication and integrity to their leaders and also the country or institution where he is ruled, as well as which subordinates do not have dedication in their work, to know the condition of all the people or subordinates 
they lead, then a leader must always carry out supervision and monitoring.In Canakya Niti Literature VI.4 the following quotation is written as "bhrahman sampujyate raja" which means "King who always goes on praise and respect". The intended journey is that a king or leader always visits each region he leads so he may know how the people really are, so that a king or leader can see, hear and feel directly about his people's aspirations, desires, and complaints. After knowing with certain conditions of the people led by a leader can design or take a policy that can improve the conditions faced by the people they lead.

\section{Mangenakang manahing wadwa bala}

A leader has an obligation to always maintain an atmosphere or situation that makes subordinates or the people they lead always feel safe, comfortable, and peaceful.

\section{Rumaksa Jroning Pura}

A leader is obliged to guard the palace and all the people inside, whether in the form of wealth, empresses, the governors and paramedics, court ladies, warriors, to the palace messengers, all of them must be maintained so that they are always safe, healthy, and prosperous.

\section{Tan Kenal ring Ala-ala}

A king (leader) should avoid doing crime, or always uphold or do good. The king (leader) who holds true to goodness (dharma) will be loved by all his people.

\section{Kinajrihan Padha Manusa}

A king (leader) should be able to maintain his authority so that he is respected by others, including by his own relatives, his people, neighbors, even opponents or competitors. Being respected doesn't mean being feared, even though it can be a part of it. A respected king (leader) is one who earns respect and obedience from those he leads. The authority of a king (leader) is stated in the Manawa Dharmasastra holy book.

\section{Catur Pariksa}

The Catur Pariksa teachings are contained in the Smarandana poems.The Catur Pariksa teachings are teachings that should be carried out by a leader in carrying subordinates with the aim of disciplining the subordinates themselves. The parts of Catur Pariksa are:

\section{Sama}

Sama, which means a leader must be able to control his subordinates, including his own friends. Maintaining the attitude of devotion to God in the subordinate or the community that is led, then the behavior of the community will always be in discipline and high integrity.

\section{Dana}

Dana means a leader must try to help his people meet their needs for clothing, food and shelter. The welfare of the people by meeting the needs of clothing, food, and shelter, is a very noble act. This is confirmed in the verses of sacred literary Sarasamuccaya.

\section{Bheda}

Bheda can be interpreted as a fair behavior towards all people without exception (Suhardana, 2008: 90). Bheda in Geguritan Niti Raja Sasana is mentioned as determination (affirmation) towards subordinates, so that subordinates or the people do not underestimate. Assertiveness is basically a reflection of determination in carrying out a principle, and determination is faith.

\section{Dandha}

The word dandha actually has the meaning of a bat, but in a deep sense the meaning of dandha is that a leader must be able to punish fairly against subordinates or to anyone who is guilty. In the Geguritan Niti Raja Sasana, dandha is defined as the ability of a leader to monitor the wedi ning wadwa, making "fear" of his subordinates and people.

\section{Sad Dasa Brata}

Sad Dasa Brata is the teaching contained in the Geguritan Niti Raja Sasana. Sad means six, Dasa means ten, and Brata means self- 
attitude. So Sad Dasa Brata can be interpreted as sixteen self-attitudes that must be carried out by a leader. The Sad Dasa Brata consists of:

Giri Brata, Indra Brata, Mretawarsa Brata, Yama Brata, Geni Brata, Lawana Brata, Mrega Brata, Singa Brata, Anila Brata, Sata Brata, Mayura Brata, Cantaka Brata, Kaganila Brata, Wyagra Brata, Cundaga Brata, Walesa Brata.

\section{Tri Tataning Kamantrian}

The Tri Tataning Kamantrian teachings are found in Pupuh Ginanti (II. 1-5). In this poem it is explained that the wealth of a king (leader) is to have mantri (minister) who are wise and can make the universe expand. The word mantri consists of two words namely man and tri, where man means virtue (important) and tri which means three.

\section{Tri Suragapan}

Tri Suragapan is a teaching that gives instructions to the king (leader) not to do three things consisting of Wikayika, Wicika, and Manasika. Tri Suragapan consists of two words namely Tri which means three, and Suragapan which in the Old Javanese dictionary unravels in the word sura-ragaapan. The word raga becomes the most important meaning in Tri Suragapan, which has the meaning of passion, furious, impatient, challenging, rash, and not thinking long. Thus, it can be interpreted that Tri Suragapan has meaning three kings (leaders) which are not patience, logical and wise, so that they are very passionate and rash for their self-help.

\section{Tri Ulahing Budhi}

Tri Ulahing Budhi's teachings of king to leading and the three actions namely Wijayastra, Sopadina, and Nagarajana are the behavior of a king (leader) based on noble Buddhism.

\section{Rukma Bhisama}

The teachings of Rukma Bhisama consist of three parts. The distribution of Rukma Bhisama is Wirya Kanuwirya, Wirya
Kasalastra and Wirya Kawasakartha.nRukma Bhisama's teachings basically emphasize the obligation of a king to always pay attention to the condition of the region and also its people. A king (leader) is absolutely not allowed to pursue only glory for himself. Rukma Bhisama has 3 parts which outline his obligations as the leader of his, such as:

Wirya Kanuwiryan emphasized that a king (leader) should always be able to maintain his every behavior to maintain his glory and authority.

Wirya Kasalastra, emphasizing that a king (leader) should not only think about himself and do not care about the condition of the people they lead.

Wirya Kawasakartha, who emphasized that a king (leader) should not be lazy in carrying out his duties and obligations.

\section{Asta Brata}

The teachings of Asta Brata is one of the most well-known leadership teachings in Hinduism and the cultural treasures of the nusantara. Related to the teachings of Asta Brata contained in the Geguritan Niti Raja Sasana consists of Indra brata, Yama brata, Baruna brata, Kuwera brata, Surya brata, Candra brata, Bayu brata, and Geni brata. Symbolizing the nature that must be possessed by a king (leader) or head of state. The behavior of a leader should have similarities with the nature of the god Indra (king of the gods), Wayu (wind god), Yama (god of death), Surya (sun god), Agni (god of fire), Waruna (god of water), Candra (the moon god), and Kubera (the god of treasure). In fact the teachings of Asta Brata are the teachings contained in the Ramayana book, which was revealed by a character named Sri Rama to the Wibhisana before he was appointed king in Alengka to replace his brother Rahwana who had died on the battlefield because he was defeated by Sri Rama. The essence of the advice given by Sri Rama to Wibisana before becoming king is that the qualities of the deity must be imitated by a king (leader) in terms of courage, listening and knowing the whole people, feared by opponents, living the universe, 
burning opponents and sin, fun, a source for all idols and philanthropists. These all will put the king in the main authority as a leader.

\section{Catur Sopeksa}

Catur Sopeksa is a teaching that teaches about the procedure for behavior, especially for a servant of a leader. The prohibitions contained in the Catur Sopeksa teachings consist of: A servant must not act or want to be treated like a king. If so the servant will be arrogant behavior, A servant is not allowed to walk before the king, or to cross the road or a place that is prohibited for a servant, A servant must not be arrogant, even more so insulting his own king, A servant is forbidden to blaspheme his lord, moreover he commits lying to his king.

\section{Catur Pariksa Nagara Krama}

The Catur Pariksa teachings in this section are different from the Catur Pariksa teachings that have been reviewed previously. Catur Pariksa in this sub is a division of Nagara Krama, which consists of Nandhana Pariksa, Istri Pariksa, Karyya Pariksa, and also Ragga Pariksa.

The parts of the Catur Pariksa teachings are as follows:

1) Nandhana Pariksa is that a king (leader) should watch out or examine carefully and even test the beauty that someone shows when facing him. At this time, the vigilance of a king (leader) is needed in order to avoid the decisions that actually plunged.

2) Istri Pariksa is a king (leader) should be wary of women. Including a king (leader) must be able to test the behavior of a woman. If a king (leader) is attracted to and intoxicated by love for a woman, then his vigilance and wisdom will fade.

3) Karya Pariksa, which can be interpreted as being aware of (guarding) a job including a job assigned to subordinates.

4) Ragga Pariksa, which is watching yourself. Supervision in this case is related to individuals. A subordinate who is suspected of wanting to misuse the government, it is important to be monitored

\section{Panca Raksa}

Panca Raksa are teachings that a king (leader) should be able to control his five senses so that they are not always excessive in fulfilling desires. As stated about Panca Raksa as follows:

Bhaya Raksana. This means that a leader must be able to always "awake" in the sense of being alert.

Srawana Raksana which means a king (leader) should be wary of any issues, rumors, or any news that is unclear and has problems with its truth.

Sparsana Raksana which teaches that a king (leader) should not be fond of or like to play in love with women. A woman has an alluring power that can blind the heart and common sense, especially if she has a beauty and attractive physical appearance.

Jitwa Raksana is to teach a king (leader) not to be too greedy in terms of consuming food. He must be able to choose foods that are clean, healthy, and truly beneficial to the body Grhana Raksana who teaches that a king (leader) should not only like the fragrance. In this case it has an understanding or intention that a king (leader) should also be able to smell fishy, rotten, and unpleasant.

\section{CONCLUSION}

The teachings of Hindu leadership in the Geguritan Niti Raja Sasana, as described in the discussion section that is about the obligations as a leader that need to be applied in leading a kingdom, state or institution in order to create a conducive and prosperous atmosphere, starting from the teachings the earliest is Dwidasa Pratingkahing Prabhu which is 12 (twelve) mandatory behaviors carried out by a king (leader. The provisions in taking subordinates in order to discipline the subordinates themselves, namely Catur Pariksa, with the following parts; Same, Dana, Bheda, dandha. Sad Dasa Brata is the teaching which is contained in Geguritan Niti Raja Sasana, concerns on the sixteen selfattitudes that must be carried out by a leader. An institution or the state can not only be led by a leader, but of course there is a minister who takes part in the government, Tri 
Tataning Kamantrian contained in Pupuh Ginanti (II. 1-5). In this passage (pupuh) it is explained that the wealth of a king (leader) is to have a mantri (minister) who is wise and can make the horizon of the universe. Prohibition for a leader as outlined in the commotion of Niti Raja Sasana, one of which is the Tri Suragapan teachings are teachings that give instructions to a king (leader) not to do three things consisting of Wikayika, Wicika, and Manasika, as well as behavioral attitudes leaders based on nobleness of Buddhism are found in the teachings of Tri Ulahing Budhi with their parts namely Wijayastra, Sopadina, and Nagarajana. In the obligation of a king or leader contained in the teachings of Rukma Bhisama which consists of three parts namely, Wirya Kanuwirya, Wirya Kasalastra, and Wirya Kawasakartha. Asta Brata which is one of the teachings contained in Geguritan Niti Raja Sasana consists of Indra brata, Yama brata, Baruna brata, Kuwera brata, Surya brata, Candra brata, Bayu brata, and Geni brata, those are the symbols of the nature that must be possessed by a king (leader) or head of state. Another teaching is Catur Sopeksa which related to the leader's behavior procedure, especially for a servant of a leader. Catur Pariksa Nagara Krama, which is also a teaching in the Geguritan Niti Raja Sasana that refers to the vigilance of a leader against influence from inside and outside. A king (leader) should be able to control his five senses so that he is not always excessive in fulfilling his desires. As mentioned about Panca Raksa, Bhaya Raksana, Srawana Raksana, Sparsana Raksana, Jitwa Raksana Grhana Raksana. Thus, the leadership teachings contains in the Geguritan Niti Raja Sasana that should be carried out by a king (leader) in carrying out his duties and obligations to lead the country and all its people in order to realize safety, peaceful and prosperous life which is the goal of Hindu religion namely Shanti (peace) and Jagadhita (prosperous life).

\section{REFERENCES}

Anand, S. (2002). The Essence of the Hindu Religion. New Delhi: Rajkamal Electric Press.

Satana, M. \& Anomdiputro, CS. (2005). Kautilya Artha Sastra. Surabaya: Paramita

Baskarananda, S. (1998). The Essentials of Hinduism. Chennai: Sri Ramakrishna Math.

Basrowi \& Suwandi. (2008). Penelitian Kualitatif. Jakarta: Rineka Cipta.

Bose, A.C. (2000). Panggilan Veda. Surabaya: Paramita

Daging, I W. (2012). Nilai-nilai Pendidikan Budi Pekerti Pada Geguritan Yasa Kerthi Karya Ida Pedanda Gde Nyoman Pidada. Tesis: PPS IHDN Denpasar.

Danim, S. (2011). Pengembangan Profesi Guru. Jakarta: Kencana

Dharmayasa, I M. (1995). Canakya Niti Sastra. Denpasar: Yayasan dharma Narada

Endraswara, S. (2011). Metodologi Penelitian Sosiologi Sastra. Yogyakarta: CAPS.

Endraswara, S. (2014). Metodologi Penelitian Sastra Bandingan. Jakarta: bukupop.

Gautama, W. B. (2009). Kamus Bahasa Bali. Surabaya: Paramita

Graham, G. (2014). Teori-teori Etika. Bandung: Nusa Media.

Huky, W. (1986). Pengantar Sosiologi. Surabaya: Usaha Nasional

Ibrahim, A. S. Ed. (2009). Metode Analisis Teks dan Wacana. Yogyakarta: Pustaka Pelajar.

Indrakusuma, A. D. (1973). Pengantar Ilmu Pendidikan. Surabaya: Usaha Nasional

Iskandar. (2010). Metodologi Penelitian Pendidikan dan Sosial. Jakarta: Gaung Persana Press

Jabrohim. Ed. (2014). Teori Penelitian Sastra. Yogyakarta: Pustaka Pelajar.

Jalaluddin, H. (2002). Psikologi Agama. Jakarta: RajaGrafindo Persada

Junus, U. (1985). Resepsi Sastra Sebuah Pengantar. Jakarta: Gramedia.

Kadir, A. (2012). Dasar-dasar Pendidikan. Jakarta: Kencana. 
Kajeng, I N. (1999). Sarasamuccaya. Satori, D. \& Komariah, A. (2009). Surabaya: Paramitha

Kaelan. (2009). Filsafat Bahasa Semiotika dan Hermeneutika. Yogyakarta: Paradigma.

Komar, O. (2006). Filsafat Pendidikan Non Formal. Bandung: Pustaka Setia

Medera, N. (1997). Kakawin dan Mabebasan di Bali. Denpasar: Upada Sastra.

Mishra, P.S. (2008). Hindu Dharma Jalan Kehidupan Universal. Surabaya: Paramita.

Metodologi Penelitian Kualitatif. Bandung: Alfabeta.

Sivananda, S. S. (2003). Intisari Ajaran Hindu. Surabaya: Paramita

Somvir. (2001). 108 Mutiara Veda. Surabaya: Paramita

Suarka, I N. (2007). Kidung Tantri Pisacarana. Denpasar: Pustaka Larasan

Suarka, I N. (2009). Telaah Sastra Kakawin. Denpasar: Pustaka Larasan.

Palguna, IBM. D. (2008). Leksikon Hindu. Sulistyorini, Dwi. 2014. Filologi Teori dan Lombok: Sadampaty Aksara Penerapannya. Malang: Madani.

Pandit, B. (2006). Pemikiran Hindu. Suradha, I M. (2007). Kamus SansekertaSurabaya: Paramita

Pudja, G. (1999). Bhagawad Gita. Surabaya: Paramitha

Pudja, G. \& Rai Sudharta, T. (2003). Manawa Dharmasastra. Jakarta: Nitra Kencana Buana

Ratna, N. K. (2007). Estetika Sastra dan Budaya. Yogyakarta: Pustaka Pelajar.

Saputra, K. H. (2010). Sekar Macapat. Jakarta: Wedatama Widya Sastra.

Saputra, K. H. (2012). Puisi Jawa Struktur dan Estetika. Jakarta: Wedatama Widya Sastra. Indonesia. Surabaya: Paramita

Surajiyo. (2008). Filsafat Ilmu dan Perkembangannya di Indonesia. Jakarta: Bumi Aksara.

Titib, I M. (1996). Veda Sabda Suci Pedoman Praktis Kehidupan. Surabaya: Paramita

Titib, I M. (2008). Wiracarita Itihasa. Surabaya: Paramita.

Wiratmadja, GK A. (1995). Kepemimpinan Hindu. Denpasar: Yayasan Dharma Naradha

Zoetmulder, P. J. (2007). Kamus Jawa Kuna Indonesia. Jakarta: Gramedia Pustaka 